\title{
Assessment of powders of Alstonia boonei (De wild) and Acalypha godseffienna (Muell Arg.) as protectants of rice grains against infestation by Sitotroga cerealella (Olivier, 1789) (Lepidoptera: Gelechiidae)
}

\section{Emmanuel Ayobami Oyeniyi}

Department of Biology. Federal University of Technology. P. M. B. 704. Akure. Ondo State. Nigeria. Email: eaoyeniyi@futa.edu.ng.

\begin{abstract}
In this study, the mothcidal efficacy of powders of Alstonia boonei (De Wild) stem bark and Acalypha godseffienna (Muell Arg.) leaf part was investigated at ambient temperature $\left(28 \pm 3{ }^{\circ} \mathrm{C}\right)$ and relative humidity $(75 \% \pm 6 \%)$. Adult Sitotroga cerealella were exposed to both botanical powders using contact toxicity test at $1-5 \mathrm{~g} / 20 \mathrm{~g}$ of paddy rice and mortality was assessed after 24, 48, 72 and $96 \mathrm{~h}$ post-treatment, respectively. The control experiment was also set-up for each botanical. Generally, both botanical powders significantly $(\mathrm{P}<0.05)$ evoked higher moth mortality when compared to control. But, none of both plant powders elicit complete moth mortality $(100 \%)$ at all the experimental dosage and exposure time. Lower dosage of $A$. boonei was however required to achieve $50 \%$ ( $24 \mathrm{~h}$ : $0.672 ; 72 \mathrm{~h}: 0.006)$ mortality in $S$. cerealella when compared to that of A. godseffienna (24 h: 1.546; $72 \mathrm{~h}: 0.238$ ). Also, A. boonei at all experimental dosage significantly reduced $(\mathrm{P}<0.05)$ emergence of $S$. cerealella when compared to control while A. godseffiana applied only at $2-5 \mathrm{~g} / 20 \mathrm{~g}$ of paddy rice significantly reduced $(\mathrm{P}<0.05)$ adult emergence when compared to control. The effect of $A$. boonei on the percentage inhibition rate of $S$. cerealella was significant $\left(\mathrm{F}_{4,15}=6.69\right.$; $\mathrm{P}=0.003$ ) while that of $A$. godseffiana was not significant $\left(F_{4,15}=1.65 ; P=0.213\right)$. It could therefore be concluded that powders of both botanicals could serve as a suitable wherewithal to most synthetic insecticides for the protection of rice grains from infestation by $S$. cerealella.
\end{abstract}

Keywords: Alstonia boonei; Acalypha godseffienna; Adult emergence; Sitotroga cerealella; Mothcidal.

\section{Introduction}

In most developing countries of the world, particularly Africa, food security is one of the best ways to attain
Received

April 27, 2018

Accepted

August 11, 2018

Released

August 31, 2018

Full Text Article

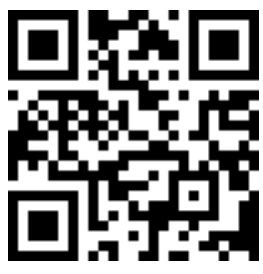

ORCID

() 0000-0003-2319-8091 Emmanuel Ayobami Oyeniyi national peace, prosperity and better living standard among the citizenry. It has however remained a mirage as several citizens still suffer from malnutrition. This has prompted the 
government of most African countries to continually import food crops to augment the little being produced indigenously. For instance, in Nigeria, It is estimated that a whopping sum of $\$ 20$ billion is being spent annually on importation of food crops like rice, maize, sorghum, wheat, among others (Nigeria Guardian, Sept. 25, 2016). But, the recent sharp drop in the international price of crude oil, the mainstay of the economy, has negatively affected the nation's income, making importation of food products nearly impossible. The resultant effect on the overall well-being of average Nigerian has been quite enormous, thus strengthening the need to diversify the nation's economy to reduce overdependence on crude oil. Agriculture has been touted as one of the suitable alternatives to achieve food security and economic prosperity in Nigeria. Consequently, past years has witnessed an increased food production aimed at meeting the local food production. Nonetheless, the country still struggles to produce enough food to feed a teeming population of over 160 million people. Apart from this, local food production in Nigeria still suffers from poor and inadequate storage facilities which have subjected most food crops to insect pest attack.

Notable among the major food crops suffering from insect pest attack is Oryza sativa (L.) commonly known as rice due to poor processing techniques. Losses of rice grains ranging from 10 to $20 \%$ of overall production has been linked to various insect pest like Rhyzopertha dominica (Fabricius), Sitotroga cerealella (Olivier), Sitophilus oryzae (Linnaeus) and Sitophilus zeamais (Motschulsky) among others (Philips and Throne, 2010; Togola et al., 2013; Gbaye et al., 2015; Akinneye and Oyeniyi, 2016). Among the various pests of rice grains, S. cerealella remained one of the most destructive as both the adults and larva stage are capable of causing havoc. In fact, the multivoltine nature of reproduction and high flight activity of the adult stage coupled with the ability of the larva stage to devour wholesome grain kernels makes this insect an infamous pest of rice. Thus, infestations by $S$. cerealella have resulted in indirect economic loss through pest control costs, quality losses and consumer complaints. In an effort aimed at tackling the various menace associated with infestation of S. cerealella, insecticides have remained the cornerstone in their management. Synthetic insecticides have however been given priority over others, especially in large scale control. But, various downsides associated with their usage continued to frustrate their continuous acceptance in most part of the world.

Against this backdrop, researchers have continued to search for other types of insecticides that meet reduced risk criteria. Notable among these types of insecticides is botanical insecticides. It is arguably believed to pose little or no threat to the people and the environment. Plant-based insecticides therefore have a critical role to play in the production and postharvest protection of food crops like rice in a developing country like Nigeria. This has given impetus to several scholars to continually search for insecticidal active plants in Nigeria. In spite of various successes reported on the usage of most plant species as an insecticide, their widespread acceptance among local farmers and consumers remained extremely disheartening. Most farmers often complain about the laborious method involved in preparation, variable efficacy, instability in the environment, unpleasant odour, poor water solubility and erratic availability among others (Isman and Grieneisen, 2014; Gbaye et al., 2016). All these have necessitated the need to continually search for new botanicals that will tackle some of the impediments associated with the existing insecticidal botanicals.

Alstonia boonei (De wild) and Acalypha godseffienna (Muell) are two 
botanicals that are chiefly available all year round in Nigeria. $A$. boonei (cheesewood) is a large deciduous, tropical-forest tree belonging to the dogbane family, Apocynaceae while A. godseffienna (copper leaf) is a very colourful tropical shrub belonging to family Euphorbiaceae (Ogundaini, 2005; Adotey et al., 2012). The mothcidal efficacy of the powder of the stem bark and leaves of A.boonei and A. godseffienna respectively against S. cerealella remained to be fully explored. Crude powders are believed to contain several phytochemicals working synergistically to augment their toxicity against insect pest (Jenson et al., 2006; Akinkurolere, 2007). Most farmers in Nigeria also prefer insecticide in powdery form due to ease of application (Personal communication, J. 0. Akinneye). Thus, the protective properties of both botanical powders against $S$. cerealella infesting rice grains in Nigeria were fully investigated in this study.

\section{Materials and Methods}

\section{Experimental location}

The experiment was carried out from February 2016 to August 2016, at the Storage Entomology Research Laboratory of Biology Department, Federal University of Technology Akure, Ondo state, Nigeria.

\section{Insect culture}

Adults $S$. cerealella used in this study were obtained from infested paddy rice sourced from Agricultural Development Program (ADP), Ondo road, Akure, Nigeria. Clean FARO-47 paddy rice variety was also obtained from Agricultural Development Program, Akure, Nigeria and disinfested in the freezer at $-10{ }^{\circ} \mathrm{C}$ for two weeks. The disinfested paddy rice grains were then allowed to equilibrate in the laboratory for three days. The moths were reared on the paddy rice variety inside $1.5 \mathrm{~L}$ plastic containers. The containers were covered with perforated lid and muslin cloth to prevent the escape of insects and to allow air into them. The moths were collected into the containers by the use of an aspirator, and they were reared for two generations on FARO-47 paddy rice variety to eliminate the effect of parent food before being used for bioassay test. The plastic containers used for insect rearing were kept inside breeding cage at ambient temperature $\left(28^{\circ} \mathrm{C} \pm 3^{\circ} \mathrm{C}\right)$ and relative humidity $(75 \% \pm 6 \%)$.

\section{powders}

\section{Preparation of the plant}

The leaves of $A$. godseffiena and A. boonei were obtained from Obanla, beside Centre for Continuing Education (CCE), Federal University of Technology, Akure, Nigeria. The bark of $A$. boonei was obtained from the Ologbo sawmill at Road block, Akure, Nigeria. The leaves and the stem bark were air dried separately for seven days in the laboratory and grinded to powder using electric blender. The grinded powders were separately sieved to pass through $180 \mu$ sieve to obtain fine powders. The powders were thereafter placed in two air-tight plastic containers and labelled accordingly prior to use.

\section{Contact toxicity}

Twenty grams of paddy rice (FAR0-47) seeds were weighed using Metler beam PB 3002 weighing balance and thoroughly mixed with $0 \mathrm{~g}$ (control), $1,2,3,4$ and $5 \mathrm{~g}$ of $A$. boonei stem bark and A.godseffiena leaf powders in $280 \mathrm{~mL}$ plastic containers. The powders and paddy rice seeds were thoroughly mixed together to ensure uniform coating of paddy rice with the powders. Five pairs of adult female moths and five pairs of adult male moths were introduced into each plastic container and covered. Each treatment was replicated four times and adult mortality was recorded after 24, 48, 72 and $96 \mathrm{~h}$ post-treatment. Both dead and live insects were removed on the fifth day and containers of the experiments were 
left for 28 days to allow for adult emergence and the number of emerged adults was counted. Inhibition rate (\%IR) in adult emergence was calculated using the method described by Tapondju et al. (2002).

$$
\% \mathrm{IR}=\frac{\mathrm{C}_{\mathrm{n}}-\mathrm{T}_{\mathrm{n}}}{\mathrm{C}_{\mathrm{n}}} \times \frac{100}{1}
$$

Where $C_{n}$ is the number of insects that emerged in the control treatment and $\mathrm{T}_{\mathrm{n}}$ is the number of adult insects that emerged in the treated grains.

\section{Data analysis}

Abbott (1925) formula was used to correct data on adult mortality counts using control mortality. All data were later subjected to one-way analysis of variance at $p<0.05$ and means were separated using Tukey's Test. Data on adult mortality were also subjected to probit analysis to determine the dosage of $A$. boonei and $A$. godseffiana needed to achieve $50 \%$ and $95 \%$ mortality in $S$. cerealella (Finney, 1971).

\section{Results}

Effect of powders of Alstonia boonei stem bark and Acalypha godseffienna leaf part on the mortality of adult Sitotroga cerealella

Table 1 and 2 shows the percentage mortality of adult $S$. cerealella exposed to powder of $A$. boonei and $A$. godseffienna respectively. Mortality of adult moth increased with increasing dosage of both botanicals and exposure time. Similarly, both botanicals significantly evoked $(\mathrm{P}<0.05)$ higher moth mortality when compared to control. However, none of both plant powders elicit complete moth mortality $(100 \%)$, even at the highest experimental dosage and exposure time. Also, no significant difference $(\mathrm{P}>0.05)$ existed in the mortality of moths exposed to all the experimental concentrations of $A$. boonei after 48, 72 and $96 \mathrm{~h}$, respectively (Table 1). On the contrary, mortality values of moths exposed to the highest experimental dosage $(5.0 \mathrm{~g} / 20 \mathrm{~g}$ of paddy rice) of $A$. godseffienna were significantly higher than those exposed to the lowest experimental dosage $(1.0 \mathrm{~g} / 20 \mathrm{~g}$ of paddy rice) after 24,48 and $96 \mathrm{~h}$ post-treatment, respectively (Tabela 2). But, no significant difference $(P>0.05)$ existed in the mortality of moths exposed to all the experimental dosage of $A$. godseffienna after 72 h posttreatment (Table 2).

Table 1. Percentage mortality of S. cerealella exposed to A. boonie powder.

\begin{tabular}{lcccc}
\hline Dosage (g/20 g of rice) & \multicolumn{4}{c}{ Exposure time (h) } \\
\cline { 2 - 5 } & $\mathbf{2 4}$ & $\mathbf{4 8}$ & $\mathbf{7 2}$ & $\mathbf{9 6}$ \\
\hline 1.0 & $57.50 \pm 2.50^{\mathrm{b}}$ & $75.00 \pm 2.89^{\mathrm{b}}$ & $87.65 \pm 9.32^{\mathrm{b}}$ & $92.90 \pm 4.44^{\mathrm{b}}$ \\
2.0 & $62.50 \pm 2.50^{\mathrm{bc}}$ & $77.50 \pm 2.50^{\mathrm{b}}$ & $87.73 \pm 2.53^{\mathrm{b}}$ & $95.40 \pm 4.60^{\mathrm{b}}$ \\
3.0 & $65.00 \pm 2.89^{\mathrm{bcd}}$ & $77.50 \pm 8.54^{\mathrm{b}}$ & $87.68 \pm 6.13^{\mathrm{b}}$ & $96.15 \pm 3.85^{\mathrm{b}}$ \\
4.0 & $75.00 \pm 5.00^{\mathrm{cd}}$ & $90.00 \pm 7.07^{\mathrm{b}}$ & $90.20 \pm 5.66^{\mathrm{b}}$ & $97.15 \pm 2.85^{\mathrm{b}}$ \\
5.0 & $76.75 \pm 1.97^{\mathrm{d}}$ & $92.50 \pm 4.79^{\mathrm{b}}$ & $95.40 \pm 4.60^{\mathrm{b}}$ & $97.73 \pm 2.28^{\mathrm{b}}$ \\
Control & $0.00 \pm 0.00^{\mathrm{a}}$ & $0.00 \pm 0.00^{\mathrm{a}}$ & $0.00 \pm 0.00^{\mathrm{a}}$ & $0.00 \pm 0.0^{\mathrm{a}}$ \\
\hline
\end{tabular}

Mean \pm SE values followed by the same superscript letter(s) down the column are not significantly different $(\mathrm{P}>0.05)$ using Turkey's Test. 
Table 2. Percentage mortality of S. cerealella exposed to A. godseffiana powder.

\begin{tabular}{lcccc}
\hline \multirow{2}{*}{ Dosage (g/20g of rice) } & \multicolumn{4}{c}{ Exposure time (h) } \\
\cline { 2 - 5 } & $\mathbf{2 4}$ & $\mathbf{4 8}$ & $\mathbf{7 2}$ & $\mathbf{9 6}$ \\
\hline 1.0 & $45.00 \pm 2.89^{\mathrm{b}}$ & $60.00 \pm 4.08^{\mathrm{b}}$ & $75.18 \pm 4.94^{\mathrm{b}}$ & $72.50 \pm 2.50^{\mathrm{b}}$ \\
2.0 & $52.50 \pm 4.79^{\mathrm{bc}}$ & $70.00 \pm 4.08^{\mathrm{bc}}$ & $82.50 \pm 4.79^{\mathrm{b}}$ & $87.70 \pm 2.30^{\mathrm{c}}$ \\
3.0 & $55.00 \pm 5.00^{\mathrm{bc}}$ & $75.00 \pm 2.89^{\mathrm{bcd}}$ & $87.50 \pm 4.79^{\mathrm{b}}$ & $87.70 \pm 2.30^{\mathrm{c}}$ \\
4.0 & $72.50 \pm 6.29^{\mathrm{cd}}$ & $80.00 \pm 7.07^{\mathrm{cd}}$ & $90.00 \pm 4.08^{\mathrm{b}}$ & $93.73 \pm 2.26^{\mathrm{c}}$ \\
5.0 & $85.00 \pm 6.45^{\mathrm{d}}$ & $92.50 \pm 4.79^{\mathrm{d}}$ & $92.50 \pm 4.79^{\mathrm{b}}$ & $95.23 \pm 2.76^{\mathrm{c}}$ \\
Control & $0.00 \pm 0.00^{\mathrm{a}}$ & $0.00 \pm 0.00^{\mathrm{a}}$ & $0.00 \pm 0.00^{\mathrm{a}}$ & $0.00 \pm 0.0^{\mathrm{a}}$ \\
\hline
\end{tabular}

Mean \pm SE values followed by the same superscript letter(s) down the column are not significantly different $(\mathrm{P}>0.05)$ using Turkey's Test.

Lethal dose ( $\left(\mathrm{L}_{50}\right.$ and $\left.\mathrm{LD}_{95}\right)$ (g/20 $\mathrm{g}$ of rice) of $A$. boonei and A.goseffiana against S. cerealella infesting rice grains

Table 3 shows the lethal dose of both botanical powders required to achieve $50 \%$ and $95 \%$ mortality in S. cerealella infesting rice grains after 24 and $72 \mathrm{~h}$ post-treatment. Positive slope of regression irrespective of the duration and botanical powder shows that moth mortality increased with increasing dosage of both botanicals. Lethal doses $\left(\mathrm{LD}_{50}\right.$ and $\left.\mathrm{LD}_{95}\right)$ of each botanical however decreased with increasing exposure time. Lower dosage of $A$. boonei was however required to achieve $50 \%$ (24 h: 0.672; $72 \mathrm{~h}: 0.006)$ mortality in S. cerealella when compared to that of A. godseffienna (24 h: 1.546; 72 h: 0.238). Also, there was significant difference $(\mathrm{P}<0.05)$ between the $\mathrm{LD}_{50}$ (after 24 and $72 \mathrm{~h}$ ) as well as $\mathrm{LD}_{95}$ (after 24 and $72 \mathrm{~h}$ ) values of $A$. boonei as inferred by their fiducial limits. Significant difference $(\mathrm{P}<0.05)$ also existed between the $\mathrm{LD}_{50}$ values of $A$. godseffiana after 24 and $72 \mathrm{~h}$. No significant difference $(\mathrm{P}>0.05)$ however existed between the $\mathrm{LD}_{95}$ values of $A$. godseffiana after 24 and 72 h posttreatment.

Table 3. Lethal dose $\left(\mathrm{LD}_{50}\right.$ and $\left.\mathrm{LD}_{95}\right)(\mathrm{g} / 20 \mathrm{~g}$ of rice) of $A$. boonei and $A$. goseffiana against $S$. cereallela infesting rice grains.

\begin{tabular}{lccccc}
\hline $\begin{array}{c}\text { Botanical } \\
\text { (g/20 g of rice) }\end{array}$ & $\begin{array}{c}\text { Exposure } \\
\text { time (h) }\end{array}$ & Slope $\mathbf{\pm}$ SE & $\boldsymbol{X}^{\mathbf{2}}$ & LD $_{\mathbf{5 0}}$ (95\% FL) & LD 95 (95\% FL) $^{\text {(95\% }}$ \\
\hline Alstonia boonei & 24 & $0.78 \pm 0.12$ & 35.19 & $0.672(0.221-1.064)$ & $87.76(28.83-1537.33)$ \\
Acalypha & 72 & $0.48 \pm 0.15$ & 241.51 & $0.006(0.000-0.012)$ & $15.135(3.123-27.147)$ \\
godseffiana & 24 & $1.43 \pm 0.12$ & 124.90 & $1.546(0.903-2.041)$ & $22.06(10.739-146.685)$ \\
\hline
\end{tabular}

SE: Standard error; $X^{2}$ : Chi square; LD: Lethal dose; FL: Fiducial limit; Values in parenthesis represents $95 \%$ fiducial limit.

\section{Adult emergence and percentage inhibition rate of $S$. cerealella in paddy rice treated with $A$. boonei and $A$. godseffiana powders The effect of both plant powders on the adult emergence of $S$. cerealella is}

presented in Figure 1. There was significant effect $(\mathrm{P}<0.0001)$ of $A$. boonei $\left(\mathrm{F}_{5,18}=22.87\right)$ and A. godseffiana $\left(\mathrm{F}_{5,18}=\right.$ 9.96) on the emergence of adult S. cerealella. Also, A. boonei at all experimental dosage significantly 
reduced $\quad(\mathrm{P}<0.05)$ emergence of $S$. cerealella when compared to control while $A$. godseffiana applied at $2 \mathrm{~g}, 3 \mathrm{~g}$, $4 \mathrm{~g}$ and $5 \mathrm{~g} / 20 \mathrm{~g}$ of paddy rice significantly reduced $(\mathrm{P}<0.05)$ adult emergence when compared to control. Likewise, $A$. boonei applied at the highest experimental dosage $(5 \mathrm{~g} / 20 \mathrm{~g}$ of paddy rice) significantly reduced $(\mathrm{P}<0.05)$ emergence of S. cerealella when compared to paddy rice exposed to $1 \mathrm{~g}$ and $2 \mathrm{~g}$ of $A$. boonei, respectively. No significant difference $(\mathrm{P}>0.05)$ however existed in the adult emergence of paddy rice exposed to $2 \mathrm{~g}, 3 \mathrm{~g}, 4 \mathrm{~g}$ and $5 \mathrm{~g}$ of A. godseffiana, respectively. Higher number of moth also emerged from paddy rice treated with $A$. godseffiana when compared to their counterpart exposed to A. boonei.

Figure 2 shows that the percentage rate of inhibition in adult emergence of $S$. cerealella reduced with increasing dosage of both powders of A. boonie and A. godseffiana. There was however a significant effect of $A$. boonei $\left(\mathrm{F}_{4,15}=6.69 ; \mathrm{P}=0.003\right)$ on the percentage inhibition rate of $S$. cerealella. However, the effect of $A$. godseffiana on the inhibition rate of $S$. cerealella was not significant $\quad\left(\mathrm{F}_{4,15}=1.65 ; \quad \mathrm{P}=0.213\right)$. A. boonei applied at the highest experimental dosage $(5 \mathrm{~g} / 20 \mathrm{~g}$ of paddy rice) significantly inhibited emergence of
S. cerealella in paddy rice when compared to inhibition rate in paddy rice treated with $1 \mathrm{~g}$ and $2 \mathrm{~g}$ of $A$. boonei respectively. But, neither of the two botanical powders elicited complete inhibition in adult emergence of $S$. cerealella at all the experimental dosage.

\section{Discussion}

The use of plant materials as an entomocide is a common and age-long practice in Nigeria and other African countries. Consequently, plant parts of several floras have been investigated for their insecticidal activities against stored product pests and this has helped in reducing losses associated with most of these pests. In this study, the effectiveness of powders of Alstonia boonie stem-bark and Acalypha godseffiana leaves as a protectant agent was investigated. Both plant powders evoked moth mortality irrespective of the experimental dosage and exposure time. This demonstrates the mothcidal potential of both botanicals against Sitotroga cerealella, thus corroborating similar observation made by Ashamo et al. (2013) and Akinneye and Oyeniyi (2016). However, the effectiveness of both botanical powders against $S$. cerealella varied with their doses and exposure periods.

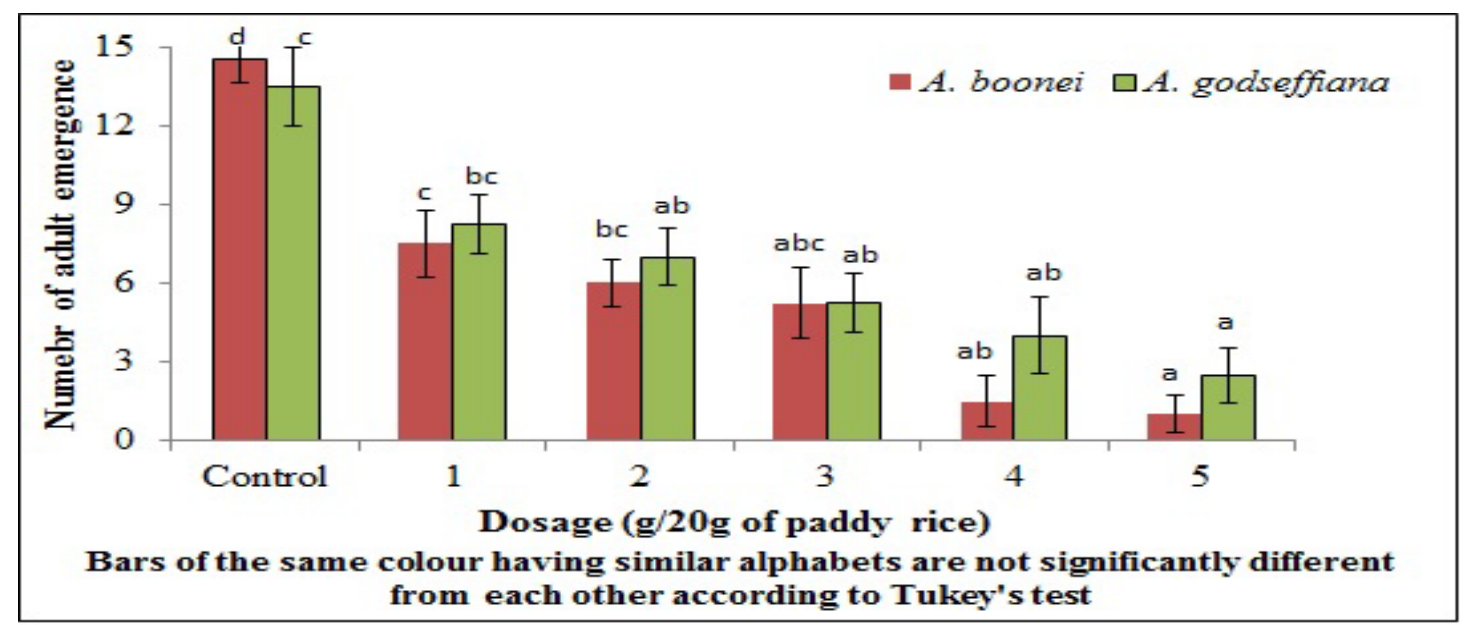

Figure 1. Effect of powders of $A$. boonei and A. godseffiana on the emergence of S. cerealella infesting paddy rice. 


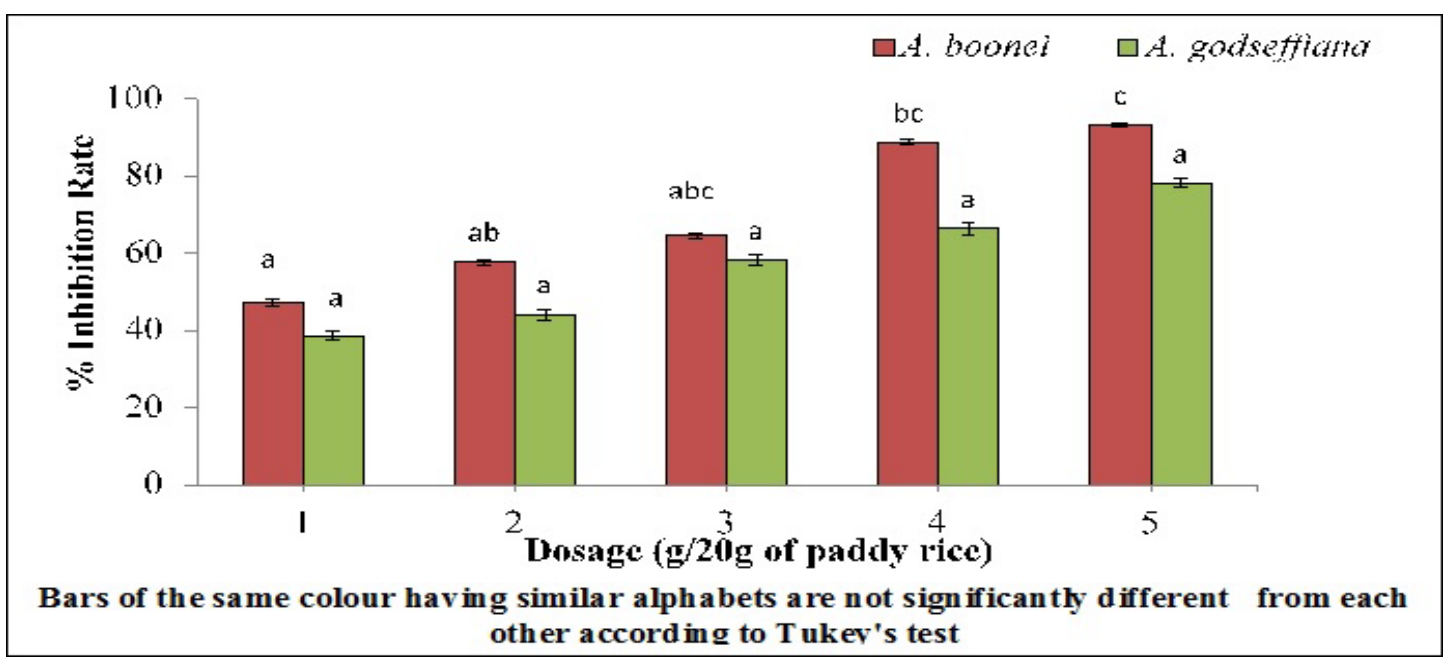

Figure 2. Percentage inhibition rate of $S$. cerealella in paddy rice treated with powders of $A$. boonei and $A$. godseffiana.

Lower values of lethal doses $\left(\mathrm{LD}_{50}\right.$ and $\mathrm{LD}_{95}$ ) of $A$. boonie compared to A. godseffiana showed higher toxicity of the former against $S$. cerealella when compared to the latter. This may be attributed to moderate to high occurrence of phytochemical compounds in A. boonei stem bark when compared to that of A. godseffiana (Oyarinde, 2016). Similarly, Fashola and Egunyomi (2005), Basu et al. (2007) and Oyarinde (2016) reported higher occurrence of saponins, flavonoids and alkaloids in $A$. boonei than in A.godseffiana. Most of these compounds have been established to be highly insecticidal to several stored product pests. For instance, Ogungbite and Oyeniyi (2014) as well as Akinneye and Oyeniyi (2016) have earlier linked the insecticidal efficacy of some botanicals to these phytochemical compounds. This may be responsible for higher efficacy of powders of $A$. boonei stem bark when compared to that of A. godseffiana leaves.

Also, powders of both botanicals significantly reduced emergence of S. cerealella when compared to control. This confirms the possible obvious effect of $A$. boonei and A. godseffiana powders on the post embryonic survival of S. cerelealla. This in turn might have significantly reduced adult emergence from treated paddy rice when compared to control. However, the emergence of fewer adults in $A$. boonei treated paddy rice when compared to $A$. godseffiana treated grains may further be ascribed to fewer phytochemical compounds, especially alkaloids in the latter when compared to the former (Oyarinde, 2016). Alkaloids have been generally reported to disrupt insect life cycle by reducing the growth and survival of larva and adult insect respectively (Ogungbite and Oyeniyi, 2014). This work is therefore in agreement with the findings of Ashamo and Akinnawonu (2012), Akinneye and Ogungbite (2013) as well as Ogungbite et al. (2014) where powders of different plant materials successfully prevented eclosion of adult insects.

Equally, there was significant effect of A. boonei on the percentage inhibition rate of S. cerealella. However, the effect of A.godseffiana on the inhibition rate of $S$. cerealella was not significant. Neither of the two botanicals elicited complete inhibition in adult emergence of S. cerealella at all the experimental dosage. No significant difference also existed in the inhibition rate of $S$. cerealella treated with 
A. godseffiana. The high inhibition in adult emergence observed at the highest experimental dosage $(5 \mathrm{~g})$ of $A$. boonei when compared to A. godseffiana may be ascribed to more chemical compositions, particularly alkaloids in $A$. boonei when compared to A. godseffiana.

\section{Conclusion}

Overall, this study has clearly demonstrated the protective properties of both botanical powders on rice grains against infestation by $S$. cerealella. However, A. boonei was observed to possess more insecticidal and adult emergence inhibition properties than $A$. godseffiana. Both botanicals could therefore be recommended to poor resource farmers for protection of rice grains against $S$. cerealella infestation in Nigeria. This will go a long way in boosting production of rice through the reduction in the amount of losses associated with this insect pest infestation on rice grains.

\section{Conflict of Interest Statement}

The author of this work declares that there is no conflict of interest.

\section{References}

Abbott, W. S. A method for computing the effectiveness of an insecticide. Journal of Economic Entomology, v. 18, p. 265-267, 1925.

Adotey, J. P. K.; Adukpo, G. E; Boahen, Y. O.; Armah, F. A. A review of the ethnobotany and pharmacological importance of Alstonia boonei De Wild (Apocyanaceae). International Scholarly Research Network Pharmacology, v. 2012, Article ID 587160, 2012 . https://doi.org/10.5402/2012/ 587160

Akinkurolere, R. O. Assessment of the insecticidal properties of Anchomanes difformis (P. Beauv.) powder on five beetles of stored produce. Journal of Entomology, v. 4, p. 51-55, 2007.

Akinneye, J. O.; Ogungbite, O. C. Insecticidal activities of some medicinal plants against
Sitophilus zeamais (Motschulsky) (Coleoptera: Curculionidae) on stored maize. Archives of Phytopathology of Plant Protection, v. 46, no. 10, p. 1206-1213, 2013.

Akinneye, O. A.; Oyeniyi, E. A. Insecticidal efficacy of Cleistopholis patens (Benth) powder against Sitotroga cerealella (Olivier) (Lepidoptera: Gelechiidae) infesting rice grains in Nigeria. Journal of Crop Protection, v. 5, no. 1, p. 1-10, 2016.

Ashamo, M. O.; Odeyemi, O. 0.; Ogungbite, 0. C. Protection of cowpea, Vigna unguiculata $L$. (Walp.) with Newbouldia laevis (Seem.) extracts against infestation by Callosobruchus maculatus (Fabricius). Archives of Phytopathology of Plant Protection, v. 46, no. 11 , p. 1295-1306, 2013.

Basu, S. K.; Thomas, J. E.; Acharya, S. N. Prospects for growth in global nutraceutical and functional food markets: A Canadian perspective. Australian Journal of Basic Applied Science, v. 1, no. 4, p. 637-649, 2007.

Fashola, T. R.; Egunyomi, A. Nigerian usage of bark in phytomedicine. Ethnobotany Research and Applications, v. 3, p. 73-77, 2005.

Finney, D. J. Probit analysis. Cambridge, London: Cambridge University Press, 1971.

Gbaye, O. A.; Oyeniyi, E. A.; Adekanmbi, F. The efficacy of three plant powders as an entomocide against Sitophilus oryzae (Linnaeus) infesting rice grains in Nigeria. International Journal of Research Studies in Zoology, v. 1, n. 1, p. 30-35, 2015.

Gbaye, O.A.; Oyeniyi, E.A.; Ojo, O.B. Resistance of Callosobruchus maculatus (Fabricius) (Coleoptera: Bruchidae) populations in Nigeria to Dichlorvos. Jordan Journal of Biological Sciences, v. 9, n. 1, p. 41-46, 2016.

Isman, M. B.; Grieneisen, M. L. Botanical insecticide research: many publications, limited useful data. Trends in Plant Science, v. 19, no. 3, p. 140-145, 2014.

Jenson, T. G.; Palsson, K.; Borg-Karlson, A. K. Evaluation of extracts and oils of mosquito (Diptera: Culicidae) repellent plants from Sweden and Guinea-Bissau. Journal of Medical Entomology, v. 43, p. 113-119, 2006.

Ogundaini, A. O. From Greens into Medicine: Taking a lead from nature. Oduduwa Hall, Obayemi Awolowo, 
University, Ile-Ife, Nigeria: OAU Press, 2005. (Inaugural Lectures Series, 176).

Ogungbite, O. C.; Oyeniyi, E. A. Newbouldia laevis (Seem) as an entomocide against Sitophilus oryzae and Sitophilus zeamais infesting maize grain. Jordan Journal of Biological Science, v. 7, no. 1, p. 49-55, 2014. Ogungbite, O. C.; Odeyemi, O. O.; Ashamo M. 0 . Powders of Newbouldia laevis as protectants of cowpea seeds against infestation by Callosobruchus maculatus (Fab.) for poor resource farmers. Octa Journal of Biosciences, v. 2, no. 1, p. 40-48, 2014.

Oyarinde, A. J. Bioactivity of two botanical extracts against Sitophilus oryzae (Linnaeus) and Sitophilus zeamais (Motschulsky) infesting wheat grains.
Akure, Nigeria: Federal University of Technology Akure, 2016. (Thesis of Bachelor Degree).

Phillips, T. W.; Throne, J. E. Biorational approaches to managing stored-product insects. Annual Review of Entomology, v. 55, p. 375-397, 2010.

Tapondju, I. A.; Alder, A.; Fontem, H.; Fontem, D. A. Efficacy of powder and essential oil from Chenopodium ambrosioides leaves as postharvest grain protectants against six stored products beetles. Journal of Stored Products Research, v. 38, p. 395-402, 2002.

Togola, A.; Seck, P. A.; Glitho, I. A.; Diagne, A.; Adda, C.; Toure, A.; Nwilene, F. E. Economic losses from insect pest infestation on rice stored on-farm in Benin. Journal of Applied Science, v. 13, n. 2, p. 278-285, 2013. 